\title{
Disciplinando a los curas: Inmunidad personal del clero y control real en el virreinato del Perú, 1755-1775 1
}

\author{
por \\ Sergio Miguel Huarcaya ${ }^{2}$ \\ Universidad del Pacífico, Lima, Perú
}

\begin{abstract}
En las últimas décadas del siglo XVIII, la corona borbónica se empeñó en socavar la inmunidad personal del clero. Examinando dos atropellamientos a autoridades reales por parte de curas doctrinarios, esta investigación analiza la capacidad de maniobra política de la Corona y la Iglesia en el virreinato del Perú, antes de la promulgación de limitaciones legales a tal exención. Una de las víctimas fue el gobernador político y militar de Tarma, quien estaba a cargo de reprimir la rebelión india de Juan Santos Atahualpa. A pesar de no lograr que el tribunal eclesiástico castigue satisfactoriamente a los curas, la Corona aprovechó la disputa para fortificar una posición regalista.
\end{abstract}

Palabras Clave: inmunidad personal del clero; jurisdicción eclesiástica; reformas borbónicas; virreinato del Perú.

Cómo citar este artículo / Citation: Huarcaya, Sergio Miguel, "Disciplinando a los curas: Inmunidad personal del clero y control real en el virreinato del Perú, 1755-1775", Revista de Indias, LXXVIII/274 (Madrid, 2018): 757-787. https://doi.org/10.3989/revindias.2018.023.

La inmunidad personal del clero en el Perú colonial, que eximía a los curas de la justicia ordinaria, ha recibido poca atención de la investigación histórica. Uno de los pocos estudios importantes es el de Margaret Crahan, que examina la disputa entre el virrey Melchor de Navarra y Rocafull, duque

\footnotetext{
1 Agradezco a Carlos Gálvez Peña y Elio Vélez Marquina, así como a los revisores anónimos de la Revista de Indias, por sus útiles comentarios y sugerencias en la preparación de este artículo.

2 sm.huarcayaf@up.edu.pe, ORCID iD: https://orcid.org/0000-0002-8339-4839. de uso y distribución Creative Commons Reconocimiento 4.0 Internacional (CC BY 4.0).
} 
de la Palata, y el arzobispo Melchor de Liñan y Cisneros, en 1684. Intentando impedir los frecuentes abusos que cometían los curas en perjuicio de los indios, el virrey había promulgado un decreto que autorizaba a corregidores $\mathrm{y}$ otras justicias reales a realizar investigaciones extrajudiciales cuando se presentaran tales casos; pero el decreto «provocó la ira de la Iglesia Católica bajo el fundamento de que era una invasión de su autoridad y una clara violación de la inmunidad eclesiástica» ${ }^{3}$. La Corona, según Crahan, no estaba dispuesta o no era lo suficientemente fuerte para aprovechar la disputa y consolidar una posición regalista. El virrey de la Palata no recibió apoyo de Madrid 4 .

En contraste, siete décadas más tarde, la corona borbónica iniciaría decisivamente una serie de reformas administrativas y legales para subordinar a la Iglesia, redefiniendo su jurisdicción y prescindiendo del balance de poder entre ambas instituciones que había caracterizado al reinado Habsburgo. Mientras que las reformas borbónicas de la primera mitad del siglo XVIII se enfocaron en controlar y proteger el comercio transatlántico, las reformas después de la Guerra de la Oreja de Jenkins (1739-1748) implicaron una «reexaminación del rol de los grupos de interés dentro del imperio, incluyendo la relación tradicionalmente cercana entre iglesia y estado» ${ }^{5}$. Los reformadores españoles emularon crítica y activamente ideas de la Ilustración de sus competidores imperiales, Francia e Inglaterra, y combinaron estas ideas con iniciativas reformistas provenientes de las colonias ${ }^{6}$. Las reformas eclesiásticas se enfocaron en limitar los ingresos de la Iglesia, que eran considerados como pérdidas para el arca real, y socavar el privilegio eclesiástico, que era considerado como un lastre para la mejora de la administración colonial ${ }^{7}$.

La serie de reformas eclesiásticas se inició en 1749, bajo el reinado de Fernando VI, quién ordenó la secularización de las doctrinas de indios en las arquidiócesis de Lima, México y Santa Fe de Bogotá, transfiriéndolas del clero regular, las órdenes religiosas, al clero secular, la iglesia diocesana ${ }^{8}$. Sin embargo, será Carlos III, el sucesor en el trono tras la muerte de su hermano Fernando VI, quien implementará un programa general de reforma administrativa y legal de la Iglesia. En el virreinato del Perú, el virrey Manso de Velasco (1745-1761) fue quien llevó a cabo la secularización de las doctrinas;

\footnotetext{
3 Crahan, 1976: 224. Todas las traducciones de textos en inglés al castellano son mías.

4 Crahan, 1971: 409.

5 Kuethe y Andrien, 2014: 167.

6 Paquette, 2011: 30-32. Kuethe y Andrien, 2014: 167.

7 Lynch, 2012: 67.

8 El proceso de secularización de las doctrinas se explica en Andrien, 2009: 190-199.
} 
mientras que el virrey Amat y Junient (1761-1776), a cargo de la expulsión de los jesuitas en 1767, fue el reformador borbónico más importante9 .

Basándose en el regalismo, una nueva doctrina jurídica de las relaciones entre la Iglesia y la Corona que argumentaba que el rey «había recibido directamente de Dios la autoridad para actuar como su vicario general», las reformas le dieron a la Corona un control sin precedentes sobre la disciplina eclesiástica ${ }^{10}$. En la implementación de estas reformas en el Perú colonial, según John Fisher, «las obstrucciones de parte de los prelados en asuntos de disciplina fueron raras» ${ }^{11}$. En contraste, en Nueva España, las reformas resultaron en protestas significativas por parte del arzobispo de México y los obispos de Puebla y Michoacán ${ }^{12}$. Por un lado, como afirma John Lynch, los jueces eclesiásticos en la América española fueron cada vez más propensos a aceptar los intereses de la Corona. Como los nombramientos y los ascensos de los eclesiásticos estaban en manos del rey, «muchos clérigos sabían que defender causas eclesiásticas que no coincidían con los intereses de la burocracia real podía dañar sus carreras $\rangle^{13}$. Por otro, el socavamiento del fuero eclesiástico llevó a algunos curas en ambos virreinatos, bastante más en Nueva España que en el Perú, a apoyar las causas independistas posteriores, al considerar que las reformas confrontaban no sólo a la Iglesia sino también a la religión ${ }^{14}$.

Considerando que la reforma de la inmunidad personal del clero fue un proceso emergente e inacabado, este estudio analiza la capacidad de maniobra política de los agentes reales y eclesiásticos en el virreinato del Perú antes de la derogación parcial de tal exención —en 1795- y demuestra un proceso más conflictivo de resistencia clerical. La evidencia proviene de dos casos de atropellamientos a autoridades reales por curas doctrinarios. Los casos, que duraron desde 1756 hasta 1771, son examinados en reales cédulas, procedimientos judiciales y memorias de gobierno virreinales ${ }^{15}$.

\footnotetext{
9 Ruiz Peralta, 1999: 177.

10 Fisher, 2000: 84-85. Taylor, 1996: 14.

11 Fisher, 2000: 84.

12 Jaramillo, 1996: 158.

13 Lynch, 2012: 69. Ver también Farriss, 1968: 93-94.

14 Fisher, 2000: 86. Cahill, 1984: 276. Farriss, 1968. Brading, 1981.

15 Los documentos examinados se encuentran en el Archivo General de la Nación, Lima (AGN); en el Archivo Arzobispal de Lima (AAL); y en la Colección Obadiah Rich (COR) de la Biblioteca Pública de Nueva York, EE.UU. Los últimos, reales cédulas, son copias hechas a mano en España en el siglo XVIII y están disponibles en microfilm. Mediante comparación extensa, estas reales cédulas han sido verificadas como copias exactas por Edwin B. Brownrigg, el autor del inventario e índice de la colección. Además, la mayoría han sido publicadas
} 
Para la Iglesia, lo que estaba en juego no sólo eran carreras o sentencias individuales sino también el evitar sentar precedentes judiciales que fueran a menoscabar la inmunidad del clero y el prestigio de la Iglesia ${ }^{16}$. A nivel de la administración colonial, lo que estaba en juego desbordaba la rivalidad entre la Corona y la Iglesia. Los casos ocurrieron en los años que Steve Stern llama «la era de insurrección andina». Entre 1720 y 1790, los indios del virreinato del Perú se levantaron más de cien veces, a veces acompañados o liderados por mestizos o criollos, en abierta resistencia a la autoridad colonial ${ }^{17}$. Según Stern, los cambios en la economía política, las políticas de estado y la demografía minaron las estrategias previas de resistencia india, erosionaron la autoridad colonial y llevaron a los indios a optar por la violencia colectiva para reclamar lo que consideraban como sus derechos ${ }^{18}$. En tal contexto, las autoridades coloniales temían que rebeliones locales se convirtieran en levantamientos generales.

Si bien durante la colonia los enfrentamientos entre curas y autoridades reales menores eran bastante comunes, los casos son particularmente significativos porque ocurrieron cuando la Corona había fracasado en extinguir la importante rebelión india de Juan Santos Atahualpa, vigente en la selva de montaña de la provincia de Tarma desde 1742. Los curas de Tarma, además, atropellaron no a una autoridad menor sino al «gobernador político y militar, comandante general en jefe» de la provincia ${ }^{19}$, quien estaba a cargo de reprimir la rebelión. La afrenta a tal autoridad política y militar exacerbó las maniobras políticas de ambas partes. A pesar de no lograr que el tribunal eclesiástico castigara satisfactoriamente a los curas, la Corona aprovechó la disputa para reforzar una posición regalista, advirtiendo al clero que tales acciones ya no eran permisibles y marcando el inicio del socavamiento de la inmunidad clerical, una protección corporativa que se remontaba a los primeros años del cristianismo.

El 18 de enero de 1758, el rey de España Fernando VI expidió una real cédula al virrey del Perú José Manso de Velasco Conde de Superunda acerca de unos «escandalosos atropellamientos practicados en aquellos dias por algunos curas de ese Arzobispado contra mis Reales ministros». El cura de la

en las Memorias de los Virreyes que han Gobernado el Perú, Tomo Tercero, Armendaris y Mendoza, Lima, Librería Central de Felipe Bailly, 1859.

16 Escamilla, 1998: 58 y 66.

17 Stern, 1990: 34.

18 Ibidem: 31.

19 Pablo Sáes de Bustamante, gobernador politico y militar y comandante general en jefe de Tarma informa acerca de excesos y sedición que cometía Andrés Castellanos, 9 de Septiembre de 1757, AGN, Superior Gobierno (SG), legajo 12, exp. 214. 
villa costeña de Chancay, Joseph Xavier de Vargas, le había propinado al teniente de corregidor Francisco de la Mata una paliza tan violenta que este tuvo que ser trasladado a Lima para recibir atención médica y convalecer en cama. Asimismo, en la provincia de Tarma, los curas Manuel de Arteaga y Joseph Gallardo habían atacado al gobernador Pablo Sanz de Bustamante ${ }^{20}$, con el agravante de que en el asalto habían impulsado una turba de indios. Bajo ninguna circunstancia, se indica en la cédula, aquellos crímenes debían quedar impunes. Las causas se deberían seguir «en todas las instancias, hasta la competente imposicion de penas para la devida correccion de los delitos, y excesos que resulten comprovados», para mantener «el devido respecto á mis jueces Reales y se asegure el resguardo y tranquilidad de esos mis Dominios $»^{21}$.

Trece años más tarde, el 28 de noviembre de 1771, el siguiente rey de España, Carlos III, expidió otra real cédula al siguiente virrey del Perú, Manuel Amat y Junient, expresando su desagrado con las penas que el tribunal eclesiástico, primero en Lima y luego en Huamanga, había dictado para los curas Arteaga y Gallardo, «sin atender á lo pedido por parte de mi Real Fisco». De acuerdo a la cédula, las repercusiones eran serias, «resultando de este exemplar las funestas consecuencias de que se repitan semejantes excesos, vivan consternados y atemorizados por los curas los Corregidores y demás personas que exercen la jurisdiccion Real». Las penas, que no se indican en la cédula, eran «tan ligeras, que mas parecen aprovacion que castigo de los excesos que cometieron con desacato y ultrage de la Real justicia que administravan los ofendidos» ${ }^{22}$.

En la misma cédula, se señala que el cura Gallardo ya había muerto sin haber recibido ninguna pena y se pregunta al virrey por qué Vargas, el cura de Chancay, nunca había sido llevado a juicio. La cédula concluye indicando al virrey a que convoque al cura Arteaga para informarle que el rey estaba sumamente insatisfecho con las ligeras penas, ya que no correspondían de ningún modo con la gravedad de los insultos. Además, el virrey debía advertir al cura que sólo por benignidad real no se le desterraba de los dominios reales; lo cual se pondría en práctica, si el cura ofendía otra vez a su majestad

20 El apellido del gobernador lo escriben de varias formas: Sanz, Sans, Sáes, Saenz y Sáenz.

21 Al Virrey de el Perú, previniéndole lo resuelto sobre los varios excesos que participó cometen algunos curas de el Arzobispado en ofensa de la jurisdicción real, 18 de Enero 1758, COR, Folio Rich 83, 27r-33v.

22 Sobre los excesos cometidos contra el Governador de Tarma por dos curas de aquella provincia, y contra el theniente de Corregidor de Chancay, 28 de Noviembre de 1771, COR, Folio Rich 83, 1r-3r. 
en la persona de sus administradores de justicia ${ }^{23}$. La explícita insatisfacción de la Corona apuntaba a criticar no sólo a los crímenes sino también a la incapacidad del tribunal eclesiástico de imponer sentencias adecuadas.

En el programa borbónico de reforma de la Iglesia, un asunto clave era imponer límites a la inmunidad personal del clero, «un privilegio corporativo hacía ya tiempo difunto en la mayor parte de Europa» ${ }^{24}$. Los reformadores de la Corona consideraban que dicha exención llevaba a crímenes y vicios intolerables, de los cuales la sociedad no tenía ninguna protección porque los clérigos carecían de un control efectivo y directo. Los clérigos también estaban propensos a criticar a la autoridad real ya que se consideraban exentos de su jurisdicción. En última instancia, la inmunidad personal del clero era un obstáculo para la racionalización de la administración de las colonias, que los reformadores consideraban como imprescindible para el desarrollo económico del Imperio español ${ }^{25}$.

\section{REGALISMO BORBÓNICO}

Según William B. Taylor, el absolutismo borbónico desplazó la metáfora parental de la Corona como el padre y la Iglesia como la madre de la familia hispana con una «concepción totalmente masculina de la política, con una sola cabeza y un sólo padre, el rey» ${ }^{26}$. En lugar de considerar a la Iglesia y al Estado como socios equivalentes y mutualmente dependientes, como los Habsburgo lo habían hecho, los Borbones se propusieron subordinar a la Iglesia, basándose en la doctrina del regalismo. Como doctrina jurídica institucionalizada de las relaciones entre la Iglesia y la Corona, el regalismo o regalía soberana patronal concebía a los reyes españoles como poseedores de derechos de gobierno en virtud de su propia condición como soberanos y no de concesiones pontificias. El regalismo, por lo tanto, es el extremo secular de la trilogía patronato-vicariato-regalía, la secuencia de doctrinas jurídicas que rigieron las relaciones entre Iglesia y Corona durante la época colonial ${ }^{27}$.

El patronato era la concesión papal al rey de soberanía sobre los territorios conquistados en las Américas, a condición de la obligación de la Corona de cristianizar a los indígenas. El vicariato, en vigor desde el año 1580 con las

\footnotetext{
23 Idem.

24 Lynch, 2012: 70.

25 Fisher, 2000: 85. Farriss, 1968: 92.

26 Taylor, 1996: 13.

27 De la Hera, 1992: 85.
} 
políticas centralizadoras de Felipe II, era el derecho de la Corona para intervenir en asuntos eclesiásticos no relacionados con el dogma religioso, en virtud de la delegación implícita o explícita del papa. Por último, la regalía determinaba que los derechos de gobierno sobre asuntos eclesiásticos eran intrínsecos a la Corona; eran derechos reales que el papado debería respetar como inalienables ${ }^{28}$. Como se expresa en una real cédula del 14 de julio de 1765, la autoridad del papa en América le había sido devuelta al rey Fernando VI. A través de una combinación de patronato y delegación divina directa, el rey determinó tener autoridad sobre todos los aspectos de la jurisdicción eclesiástica, «salvo en la potestad de orden, los poderes sacramentales adquiridos por el clero mediante su ordenación» ${ }^{29}$.

Siguiendo el ejemplo de otros países europeos, especialmente donde la reforma luterana había incrementado el poder de los monarcas, los Borbones se propusieron reformular la jurisdicción de la Iglesia ${ }^{30}$. Para convencer a las autoridades eclesiásticas de brindar su apoyo al regalismo, la Corona organizó concilios provinciales en los territorios coloniales ${ }^{31}$. El regalismo no sólo era una política de supremacía civil. Como sostiene Gabriel Paquette, el regalismo también era una nueva ideología de gobernanza, de tecnologías, modos y procedimientos de administración de poblaciones. Emulando a los expertos ingleses de economía política, los reformadores borbónicos pensaban que estas ideas pasarían a ser parte de la conducta cotidiana de todos los habitantes y contribuirían a incrementar la felicidad pública en los dominios españoles ${ }^{32}$.

Las reformas eclesiásticas incluyeron la reducción de la jurisdicción legal de la Iglesia, la secularización de las doctrinas, la visita general de reforma de las órdenes religiosas, la subordinación de la Inquisición, la expulsión de los jesuitas, el recorte del derecho de asilo y la imposición de limitaciones a la inmunidad personal del clero. Los curas doctrineros, a menudo en la intersección entre los indígenas y las autoridades reales, eran una gran preocupa-

28 Idem.

29 Fisher, 2000: 84.

30 Ibidem: 85.

31 De la Hera, 1992: 91

32 Paquette, 2011: 41-42 y 57-67. El ministro de Felipe V, José de Campillo (1693-1743), incluso propuso que tal prosperidad debía llegar a los indios. Según él, la prosperidad de las Indias dependía de integrar completamente a los indios como productores y consumidores de la economía imperial, otorgándoles privilegios políticos y sociales similares a los españoles. Véase Andrien, 2009. 
ción para la Corona ya que eran vistos como bastiones de ineficiencia e insubordinación ${ }^{33}$.

Para el virrey Amat y Junient, el principal objetivo de las obligaciones de los curas era dar el ejemplo y asistir a sus feligreses con caritativo celo. Sin embargo, según el virrey, no era posible que haya hombres tan perfectos que no cayeran en algunos vicios o «degeneren totalmente en perbersas costumbres». Si se desviaban de la observancia religiosa, era indispensable castigarlos; y en ciertos casos, había que privarlos de sus ministerios ya que en lugar de una sana doctrina inficionaban los ánimos y corrompían la disciplina eclesiástica ${ }^{34}$.

La Corona pretendía profesionalizar al clero, exigiendo que los curas se concentren únicamente en el bienestar espiritual de sus feligreses y que limiten su participación en otras actividades, tales como cátedras, actividades comerciales y asuntos judiciales o administrativos. Fundamentalmente, la Corona consideraba que el interés de los curas en el enriquecimiento personal los había corrompido ${ }^{35}$.

\section{LOS ESCANDALOSOS ATROPELLAMIENTOS}

En la real cédula del 18 de enero de 1758, expedida por Fernando VI, se explica cómo el virrey Manso de Velasco había recibido el testimonio del teniente de corregidor Francisco de la Mata. Recuperándose en Lima, De la Mata no pudo presentarse ante el fiscal y escribió al virrey para llevar a juicio al agresor y recobrar su honor. Subsiguientemente, el virrey envió una carta al rey describiendo el atropellamiento.

En la cédula, se hace un recuento de lo que el virrey había escrito. Joseph Xavier de Vargas, el cura de Chancay, había excedido su autoridad al nom-

33 Ruiz Peralta, 1999: 177-178. Taylor, 1996: 12-14.

34 Amat y Junient, 1947: 68.

35 Al Virrey del Perú, previniéndole los términos en que deben entenderse la ley y cédula que se citan sobre que los curas no tengan cáthedras, 11 de Mayo de 1756, COR, Folio Rich 83, 22r-24v. Al Virrey de el Perú, aprovando lo executado por su antecesor, para que Fr. Francisco Pacheco, de la orden de la Merced, no tubiese al mismo tiempo el empleo de Provincial y el de cura en el obispado de Cusco, 3 de Agosto de 1763, COR, Folio Rich 83, 26v-27r. Al Virrey de el Perú sobre el puntual cumplimiento de las cédulas expedidas para que se pongan thenientes de curas para los parages que fueren precisos, 10 de Marzo 1770, COR, Folio Rich 83, 35r-35v. Al Virrey de el Perú para que cele que á los Indios Janaconas no les lleven sus curas derechos algunos, y que se observen los aranceles en los términos que se espresan, 24 de Marzo de 1754, COR, Folio Rich 83, 49r-51v. 
brarse a sí mismo juez de los indios locales. Vargas había impuesto excesivas obvenciones - los honorarios para realizar bautismos, matrimonios, funerales y misas especiales - y los indios, considerando que tales tarifas eran ilegales, se habían negado a pagarle. Prescindiendo de la justicia real, Vargas tomó el control de la cárcel y encarceló a algunos de los indios que no habían pagado. Cuando el alcalde indio Matheo Barva se quejó, el cura intentó castigarle con azotes en la plaza y enseguida lo encarceló.

Para apaciguar al alcalde indio, el teniente de corregidor decidió ponerlo en libertad. De la Mata cogió las llaves de la cárcel, pero Vargas envió a un asistente para recuperarlas. Cuando De la Mata se negó, Vargas se enfureció y salió a la calle dando gritos. De la Mata estaba desarmado e intentó calmar al cura pero fue en vano. Tratando de «sostener su jurisdicción y respeto», De la Mata también se enfureció. Enseguida, Vargas levantó su bastón y golpeó brutalmente al teniente de corregidor, provocando un gran escándalo en la vecindad.

En la misma cédula, se explica que en la provincia de Tarma los curas de Carhuamayo y Ninacaca, Manuel de Arteaga y Joseph Gallardo, habían atentado contra la persona del gobernador Pablo Sanz de Bustamante. Los curas habían asumido ilegalmente la potestad de nombrar alcaldes indios para controlar los pueblos de sus doctrinas. El gobernador trató de bloquear estos nombramientos, designando otros alcaldes indios, pero los curas desafiaron sus órdenes. Cuando el gobernador visitó Ninacaca, él fue recibido por el alcalde nombrado por el cura Gallardo. Este alcalde llevaba una vara, el tradicional bastón de mando, en una sola pieza; mientras que el alcalde nombrado por el gobernador llevaba una vara rota.

El gobernador intentó restablecer su autoridad arrestando al alcalde indio ilegal, pero el cura Gallardo «formó un tumulto, y salió en un caballo con toda precipitacion en su busca, y llenándole de vituperios y graves contumelias, seguido de muchas personas, principalmente mugeres, logró el quitar al reo por aver sido herido el soldado que le conducia». Cuando el gobernador se retiraba, tratando de que se calmara la agitación, el cura le dio un fuerte golpe en la espalda con su bastón. El atropello obligó al gobernador a ir al pueblo de Pasco, desde donde informó de los hechos al virrey Manso de Velasco.

En la cédula se indica que como mínimo los tres curas debían ser retirados de sus deberes eclesiásticos, y se concluye refrendando la decisión del virrey que disponía que los corregidores se aseguren de que los curas no encarcelen a los indios por no pagar obvenciones. Los corregidores debían obstruir tales encarcelamientos y liberar a los prisioneros ${ }^{36}$.

${ }^{36}$ COR, Folio Rich 83, 27r-33v. 


\section{EL INDIO REBELDE}

En la misma real cédula, del 18 de enero de 1758, se afirma que el atropellamiento al Gobernador de Tarma era más grave por sus circunstancias,

... mediante á ser aquella provincia frontera de el Indio rebelde, y la que merece, y mereció mayor atencion al Gobierno, luego que aquel apóstata se dedicó desde la montaña á causar obstilidades, y poner en cuidado los pueblos de su inmedicion, por cuyo motivo expresais se mantiene alli tropa reglada, y aveis confiado en todas ocasiones su govierno á los militares mas acreditados ${ }^{37}$.

Desde 1742, Juan Santos Atahualpa lideraba una gran rebelión en la selva de montaña central, en el este de la provincia de Tarma, una área de evangelización misionera franciscana. Ya desde 1709, varios grupos étnicos del área se habían sublevado pero sin éxito ${ }^{38}$. Promoviendo la expulsión de los españoles y el establecimiento de un gobierno inca, Santos Atahualpa logró una alianza interétnica sin precedentes. La rebelión también contó con el apoyo de cientos de indios migrantes de la sierra. Atacando sorpresivamente, los rebeldes asaltaron haciendas, tomando prisioneros y apropiándose del ganado, y destruyeron fuertes, pueblos y misiones. Santos Atahualpa planeaba conseguir el apoyo de los indios de la sierra para lograr una rebelión general y tomar Lima ${ }^{39}$.

En 1744, temiendo que los indios de la sierra se plegaran a la rebelión, el virrey Villagarcía eximió a los indios de Tarma de las mitas, la provisión de trabajo forzado para las minas ${ }^{40}$. En 1746, una entrada militar al mando del general de armas José de Llamas fracasó estrepitosamente, sin encontrar a los rebeldes. El virrey Manso de Velasco había enviado la expedición desconociendo las dificultades del área en la época de lluvias ${ }^{41}$. En 1750, el general Llamas dirigió una nueva entrada y luego de considerable hostigamiento guerrillero por parte de los rebeldes, llegó hasta el pueblo de Quimirí, en el valle de Chanchamayo. Los rebeldes habían tomado este pueblo por ocho años pero

37 Idem.

38 Santamaría, 2007: 235.

39 Stern, 1990: 60-61. Amich, 1854: 182. Santamaría, 2007, ha cuestionado las interpretaciones mítico-religiosas del movimiento de Santos Atahualpa argumentando que no han filtrado la invectiva de las crónicas franciscanas. En contraste con intermediarios jesuitas, que expresaron admiración por el líder rebelde y confianza en que se podía llegar a un acuerdo de paz si se respetaban los derechos de los nativos, los franciscanos se esforzaron en representar al movimiento como una herejía.

40 Stern, 1990: 68.

41 Torre López, 2004: 77. 
se retiraron antes de la llegada de las tropas reales. Llamas ordenó quemar el pueblo y regresó a la sierra sin derrotar a los rebeldes ${ }^{42}$.

En el mismo año, 1750, las autoridades descubrieron y reprimieron conspiraciones indias en Lima, Canta y Lambayeque, antes de que llegaran a ser rebeliones. Los conspiradores en Lima, alfareros de Huarochirí, pensaban aliarse con la población afrodescendiente pero fueron delatados en junio de 1750. Sin embargo, uno de los conspiradores logró escapar y lideró una rebelión en Huarochirí, en septiembre del mismo año ${ }^{43}$. Los rebeldes en Huarochirí intentaron ponerse en contacto con Juan Santos Atahualpa pero sin éxito, y creyeron, como estaba escrito en un mensaje falsificado, que él iba a enviar un ejército de liberación de 4,000 combatientes ${ }^{44}$.

Como afirma Scarlett O'Phelan, la rebelión de Juan Santos Atahualpa «sólo se volvió una amenaza al descubrirse, en 1750, la conspiración de Lima y estallar un mes después la rebelión en Huarochirí. Fue sólo en ese momento que el temor se apoderó de la capital» ${ }^{45}$. Este miedo, que quedó claramente registrado en las actas del cabildo limeño, imaginaba que las rebeliones de la plebe y los desastres naturales eran castigos divinos, provocados principalmente por el comportamiento escandaloso de frailes, curas y monjas ${ }^{46}$. En 1746, un terremoto y maremoto había devastado Lima y el Callao, y una década más tarde, un grupo de monjas tuvieron persistentes premoniciones anunciando que bolas de fuego provocadas por la ira de Dios destruirían Lima. Las premoniciones aterraron a la población limeña y en ellas, las monjas mencionaron a Juan Santos Atahualpa. De acuerdo a Charles Walker, «lo que las premoniciones confirman es el miedo en Lima de los levantamientos so-

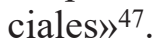

En 1752, las tropas de Santos Atahualpa tomaron la ciudad de Andamarca, en el distrito de Jauja, en la sierra. Sólo se quedaron por dos días, retirándose antes de un contraataque español, pero la bienvenida que les dieron los indios y mestizos a los rebeldes alarmó a las autoridades coloniales debido a que una insurrección general en los Andes centrales les parecía posible ${ }^{48}$. Manso de Velasco entonces propuso un plan defensivo, enviando 140 soldados de infantería a lo largo de los principales corredores entre Tarma y Jauja, y

\footnotetext{
42 Urrutia y las Casas, 1847 [1808]: 64.

43 Varese, 2006: 118. O’Phelan, 2001.

44 Stern, 1990: 66. Spalding, 1984: 287.

45 O'Phelan, 1995: 20.

46 O'Phelan, 2001: 124. Rosas Lauro, 2005: 112.

47 Walker, 2004: 54.

48 Stern, 1990: 74.
} 
50 soldados de caballería «que por la ceja de la montaña haga incesante giro ${ }^{49}$. Subsiguientes refuerzos de tropas españolas profesionales convirtieron a Tarma en una plataforma para la represión de rebeliones en los Andes centrales y norteños ${ }^{50}$.

En la campaña represiva, Sanz de Bustamante jugó un papel importante, no sólo como comandante de las tropas destacadas allí sino también como administrador real. En 1751, Fernando VI había considerado asignar gobernadores militares a las capitales de provincia del virreinato, planeando reforzar el fuero militar al mismo tiempo que debilitaba el fuero eclesiástico ${ }^{51}$. Los gobernadores militares, de acuerdo a Manso de Velasco, restablecerían la honestidad en la administración de justicia. En 1753, la Corona envió a ocho oficiales militares españoles a Lima, incluyendo a Sanz de Bustamante, vía Panamá52. Cuando vacó el corregimiento de Tarma, Manso de Velasco destinó allí a Sanz de Bustamante, dándole el título de gobernador y ascendiéndolo de teniente coronel a coronel. La tarea del nuevo gobernador era mejorar la administración civil y militar de aquella provincia, «expuesta á recibir mayores hostilidades de los Bárbaros» por su gran extensión y fronteras al descubierto ${ }^{53}$.

En 1756, Sanz de Bustamante dirigió una entrada militar hasta Quimirí, el pueblo incendiando por tropas realistas, y lo encontró reedificado, luciendo incluso una gran cruz sobre una peña, todo muy limpio, en la plaza central ${ }^{54}$. No encontrando oposición, regresó a Tarma. Después de esta entrada, no hay más noticias de la rebelión de Santos Atahualpa, pero como no fue derrotada en batalla, el temor de que seguía vigente continuó a lo largo de la década de 1770. En 1789, la Corona estableció dos fuertes para intentar reconquistar a la etnia campa, pero hasta la fundación de La Merced en 1868, gran parte de la región se mantuvo fuera del alcance del gobierno colonial $\mathrm{y}$, después de 1824, del republicano ${ }^{55}$.

Después que los curas Arteaga y Gallardo asaltaron a Sanz de Bustamante, el virrey Manso de Velasco envió un juez a Tarma a recopilar información para enjuiciar a las personas que habían participado en el tumulto ${ }^{56}$. El atropellamiento llegó a tener repercusiones en la carrera de Sanz de Bustamante.

\footnotetext{
49 Manso de Velasco, 1859 [1756]: 105.

50 Stern, 1990: 80 .

51 Ricketts, 2012.

52 Manso de Velasco, 1859 [1756]: 333.

53 Ibidem: 334. ver también COR, Folio Rich 83, 27r-33v.

54 Urrutia y las Casas, 1847 [1808]: 64.

55 Ibidem: "Introducción" y 16-17. Varese, 2006: 121 y 123.

56 COR, Folio Rich 83, 27r-33v.
} 
En su Relación de Gobierno, Manso de Velasco menciona que Sanz de Bustamante había sufrido «algunas diferencias» en Tarma que justificaron no renovar su posición como gobernador. «Por la misma razón traje de la provincia de Tarma a Pablo Saenz de Bustamante, luego que cumplió los cinco años de su provisión, y le empleé de capitán de caballos de mi guardia» ${ }^{57}$.

\section{LA REMOCIÓN DE UN CURA}

Cuando un cura era legalmente acusado de algún delito, según el virrey Amat y Junient, los procedimientos a seguir eran los siguientes. Si los cargos eran menores y los demandantes eran indios, la Corona presentaba un decreto de exhortación a la diócesis, instando al sacerdote para enmendar sus faltas y/o dar una compensación, no necesariamente económica, a las víctimas. Si los cargos eran graves y varias personas los confirmaban, la Corona solicitaba al obispo o arzobispo llevar a cabo los autos, los procedimientos judiciales. Los sacerdotes pertenecientes a las órdenes religiosas tenían dos superiores inmediatos, el obispo y el prelado de su orden. Si un cura regular cometía un delito relacionado con su trabajo eclesiástico, la petición era dirigida al obispo; si cometía un crimen de vida o muerte, la petición era dirigida al prelado de su orden.

La petición a los obispos para realizar los autos, llamada «derecho de ruego y encargo», podría complementarse con informes realizados por el fiscal del crimen de la audiencia. Si los delitos no eran muy graves, los curas culpados podían ser transferidos a otras doctrinas, en virtud de la prudencia y la discreción del obispo y en acuerdo con el vice-patrono, el virrey ${ }^{58}$.

La remoción definitiva de un cura de su doctrina, que podía incluir su expulsión de la Iglesia y la pérdida de su beneficio, se podía hacer a través de un juicio formal en un tribunal eclesiástico o a través de la Ley de la Concordia, un acuerdo legal entre el vice-patrono y el obispo que no permitía a los curas acusados defenderse. Los virreyes rara vez recurrieron a la Ley de la Concordia porque, según Amat y Junient, «muchas vezes se lebantaban calumnias en conocido perjuicio de la inocencia, y así mis Antecesores por este motivo no han querido usar» ${ }^{59}$. La Ley de la Concordia presuponía una armonía entre las autoridades eclesiásticas y reales «que no siempre existía y significaba en la práctica que cualquiera de las partes discrepantes podría

\footnotetext{
57 Manso de Velasco, 1859 [1756]: 336.

58 Amat y Junient, 1947: 9.

59 Ibidem: 69 y 70.
} 
obstaculizar con éxito los procedimientos» ${ }^{60}$. En 1768, por ejemplo, Amat obstruyó la demanda del obispo de Huamanga para remover cuatro sacerdotes a través de la Ley de la Concordia, indicando al obispo que lleve los casos a los tribunales ${ }^{61}$.

En la cédula del 18 de enero de 1758, expedida por Fernando VI, se sugiere al virrey Manso de Velasco que llegue a un acuerdo con el arzobispo Pedro Antonio de Barroeta Barroeta y Ángel: «si reconocidos los autos... se hallare estar plenamente justificados los excesos que os denunciaron, procedais á su remocion de cuerdo con el eclesiástico, y en la forma dispuesta por la ley de la concordia» ${ }^{62}$. Sin embargo, el arzobispo Barroeta rechazó la propuesta y llevó los casos al tribunal eclesiástico ${ }^{63}$.

\section{El arzobispo Pedro Antonio de Barroeta y Ángel}

En 1748, la Corona nombró a Pedro Antonio de Barroeta y Ángel como el nuevo arzobispo de Lima. Antes de viajar al Perú, Barroeta escribió a la audiencia de Lima, cuyo presidente era el virrey Manso de Velasco. En una carta desde Málaga, España, Barroeta afirmó su disposición para mantener buenas relaciones entre Iglesia y Corona: «Me sera menos ponderoso este sircunstanciado Ministerio por los saludables, y sabios consejos de V.E., y V S.S. y su gran Poder con el Norte del apreciable vinculo de la union, y corde armonia de ambas Jurisdicciones» ${ }^{64}$.

Estos comentarios se irían a contradecir durante su gestión. Barroeta fue consagrado como arzobispo de Lima el 25 de junio de 1751. Siete años más tarde, en la real cédula del 18 de enero de 1758 se expresa que Barroeta tenía un «genio delicado», un temperamento difícil y una propensión para el antagonismo. También se enfatiza el celo con que el arzobispo protegía a los eclesiásticos:

... estos pesados lances, tan indecorosos á mi Real jurisdiccion, y de perversas consecuencias al sosiego y buen govierno de esas provincias, serian fácilmente corregidos con público escarmiento, si ese Prelado se interesara como está obligado á mantener el respecto de mis ministros; pero que su genio y conducta es muy

\footnotetext{
60 Farriss, 1968: 24.

61 Amat y Junient, 1947: 70.

62 COR, Folio Rich 83, 27r-33v.

63 Amat y Junient, 1947: 71.

64 Pedro Antonio de Barrueta a la Audiencia de Lima, 22 de Agosto de 1748, COR, Folio Rich 83, 207r.
} 
contraria al logro de estos favorables efectos, porque al mismo tiempo que es muy delicado en todo lo que pertenece á su jurisdiccion, procurando estenderla... estando bien enterados los Curas de que no perderán la gracia de su Prelado, siempre que intenten embarazar á los Corregidores el uso de sus facultades haciendo que las suyas sean atendidas como superiores, pues aunque por escrito algunas veces dé á entender sumision y respeto á mis Reales ministros, no lo acredita en sus operaciones 65 .

Para entonces, los recurrentes enfrentamientos entre el virrey Manso de Velasco y el arzobispo Barroeta ya eran ampliamente conocidos ${ }^{66}$. Sus disputas, como afirma Alfredo Moreno Cebrián, «se constituyeron en motivo de amplio escándalo, con enorme trascendencia popular» ${ }^{67}$.

Estos «incidentes y tropiezos» incluyeron la disputa del parasol. El arzobispo había comenzado a utilizar un parasol en las procesiones, pero tal uso era una prerrogativa del virrey. En estos eventos, el arzobispo marchaba adelante. El problema era que un parasol requería una persona extra para llevarlo, y de acuerdo a Manso de Velasco, «seria gran indecencia que se interpusiesse un lacayo, negro ó mulato, que son los que se destinan á estos servicios, y fuese dando la espalda al Virrey ó Audiencia» ${ }^{68}$. En una real cédula expedida el 7 de junio 1754, la Corona apoyó al virrey en esta disputa. Dos años más tarde, el arzobispo Barroeta afirmaría que este incidente había sido el origen del antagonismo con el virrey ${ }^{69}$.

Barroeta defendió con extraordinario celo incluso problemas menores, y Manso de Velasco detalló sus numerosas disputas. Estas incluían, entre muchas otras, la orden del arzobispo para que el organista de la catedral toque exclusivamente cuando él entraba o salía, su intento de nombrar un favorito como profesor de derecho en la Real Universidad, y su negación de recibir las provisiones de ruego y encargo ${ }^{70}$. Tanto el virrey como el arzobispo culparon a los asesores del otro por el antagonismo ${ }^{71}$. El distanciamiento personal entre el virrey y el arzobispo dio lugar a una tutela obsesiva de sus juris-

${ }^{65}$ COR, Folio Rich 83, 27r-33v.

66 Al Arzobispo de Lima, 28 de Marzo de 1758, COR, Folio Rich 83, 119r-122v.

67 Moreno Cebrián, 1983: 52.

68 Manso de Velasco, 1859 [1756]: 8.

69 Vargas Ugarte, 1961: 127.

70 En relación a los problemas entre Manso de Velasco y Barroeta en la reconstrucción de Lima luego del terremoto de 28 de octubre de 1746, véase Walker, 2008 y Pérez-Mallaína Bueno, 2001. En relación a los problemas de jurisdicción con la Inquisición, véase Martínez Martin, 2008. También Millar Carvacho, 1986. Asimismo Walker, 2004.

71 Vargas Ugarte, 1961: 127. 
dicciones $^{72}$. Las tensiones no terminarían hasta que Barroeta dejó Lima, bajo órdenes de la Corona, para encargarse del arzobispado de Granada, España, el 18 de septiembre de 1758. Antes de partir, el arzobispo llegó a escribir que su remoción era una injusta e indignante derrota ${ }^{73}$.

En el caso de Tarma, la interacción entre el arzobispo y el virrey fue, como de costumbre, antagónica. Antes del atropellamiento, el arzobispo no había cumplido con las demandas del virrey de impedir que los curas faltaran a la autoridad del gobernador. Después del atropellamiento, el arzobispo se negó a remover a los curas de sus cargos a través de la Ley de la Concordia. Los curas, de acuerdo a la Corona, confiaban en tener el apoyo incondicional del arzobispo. En la real cédula del 18 de enero de 1758, se expresa que el cura Manuel de Arteaga, «se jactava de que no tenia que temer al Govierno, ni á los demás Ministros por hallarse obligado su prelado a sostenerle» ${ }^{74}$.

El virrey Manso de Velasco ya había expresado su descontento con la forma como se estaban llevando a cabo los procesos legales. En la misma cédula se indica que la desconfianza del virrey se fundaba no sólo en el genio del arzobispo sino también en que este había encargado la elaboración de las sumarias a otros curas de la misma provincia, quienes eran amigos y tenían las mismas pretensiones que los acusados ${ }^{75}$.

\section{LAS SUMARIAS}

El 2 de febrero de 1684, como se menciona antes, el virrey De la Palata firmó un decreto autorizando a los corregidores y sus tenientes a presentar informaciones sumarias acerca de abusos perpetrados por curas. Estos documentos, de acuerdo a Amat y Junient, podían hacerse en secreto y eran «extrajudiciales, que no tienen forma, ni naturaleza de juicio» ${ }^{76}$. Su propósito era meramente informativo. El informante escribía dos copias, una para el gobierno y la otra para la diócesis, con la intención de poner fin a las transgresiones.

Para el arzobispo de Lima, Melchor de Liñan, la ordenanza fue indignante. Según Amat y Junient, «Esta providencia destempló el animo del Eclesiastico / y se siguieron ruidosas competencias con el M. R. Arzobispo de esta Metropoli, expresando se oponía esto á la immunidad Ecclesiastica, que se

72 Moreno Cebrián, 1983: 53.

73 Barroeta y Ángel, 2008: 170.

${ }_{74}$ COR, Folio Rich 83, 27r-33v.

75 Idem.

76 Amat y Junient, 1947: 72. 
rompian las Puertas del templo de Dios, y que se despedazaba la tunica inconsutil de Cristo ${ }^{77}$. La ordenanza fue implementada pero apenas se utilizó. En 1753, Manso de Velasco propuso que la ordenanza no se debería usar a fin de evitar «los perniciosos disturbios que podrian ocurrir entre los Curas, y Corregidores», y en noviembre de 1758, la Corona confirmó y autorizó la decisión de Manso de Velasco ${ }^{78}$. El virrey y las reales audiencias todavía podían encargar a sus oficiales la preparación de informaciones sumarias sobre los actos de indisciplina de los curas pero sin involucrar a sus prelados. Ya que no implicaba a ningún fiscal, acusado, veredicto, o sentencia, su eficacia era bastante limitada ${ }^{79}$. Sin embargo, había una excepción que permitía que las justicias reales realizaran informaciones de religiosos involucrando a sus prelados. La Corona autorizó este proceder en 1565, para casos en que los religiosos hubieran cometido excesos públicos y escandalosos ${ }^{80}$.

El 10 de enero de 1757, el fiscal del crimen relacionó los dos casos como similares, «no ha muchos dias le sucedio el mismo lanze al teniente de correxidor de la villa de chancai con su cura», y pidió para ambos un tratamiento similar: llevar los expedientes al Real Acuerdo, la reunión de la audiencia en pleno ${ }^{81}$. Cuatro días después, Manso de Velasco presentó el derecho de ruego y encargo a Barroeta para que proporcione «las providencias mas oportunas afin de que se averigue el grave exceso cometido por los Curas de las doctrinas de Carguamaio, y Ninacaca con notable escandalo de aquella Provincia, en donde se hace mas preciso el respeto y sumicion, y obediencia al Caracter del Governador de ella, por las circunstancias actuales de la referida provincia» ${ }^{82}$. Manso de Velasco encargó las sumarias del caso de Tarma a Alfonso Santa de Ortega, corregidor de Canta. El arzobispo Barroeta, a su vez, encargó las sumarias a Ventura Cabello, el cura de Huariaca, otra parroquia indígena en la provincia de Tarma ${ }^{83}$.

77 Idem.

78 Al Virrey del Perú, aprovándole lo resuelto en quanto á que no se pongan en práctica las ordenanzas de el duque de la Palata que autorizan á los Corregidores para hacer informaciones sobre los procederes de los curas, 15 de Noviembre de 1758, Rich 83, 26r-26v.

79 Farriss, 1968: 42.

80 Recopilación de Leyes de los Reynos de las Indias..., 1791, Ley 73, Título 14, Libro 1: 123.

81 Pablo Sáenz de Bustamante gobernador político y militar de Tarma sobre los excesos e injurias cometidos por los curas de Carhuamayo y Ninacaca, Lima, 9 de Enero de 1757, AGN, SG, legajo 12, exp. 207.

82 Idem.

83 COR, Folio Rich 83, 27r-33. En cumplimiento del superior orden de V.E. para que pasare a esta Provincia averiguar el tumulto con que las Yndias, e Yndios de ella faltaron al debido respeto, y obediencia a su Gobernador Don Pablo Saenz de Bustamante, 11 de Enero 
Las sumarias conducidas por Santa de Ortega añaden más detalles a lo acontecido. El cura Gallardo había incitado una turba para liberar al alcalde ilegal, quien había sido arrestado por órdenes de Sanz de Bustamante. Gallardo golpeó al soldado Miguel de Arias que conducía al preso, y la turba - que de acuerdo al gobernador eran alrededor de 80 mujeres y muchachos indioslanzó piedras a los pocos soldados presentes. Después de una larga refriega, los soldados soltaron al preso. Cuando fueron a avisar a Sanz de Bustamante, Gallardo llegó enseguida y ambos se enfrentaron en acalorada discusión. De acuerdo al informe, el gobernador le recriminó: «si no fuera cura no hiciera estas maldades». Gallardo le respondió diciéndole que si no fuera gobernador no haría aquellos desórdenes. "Y tras de estas razones», el cura «lebanto el baston, y le descargo un golpe que le cogió desde el hombro hasta encima de la mollera; Yba a repetir otro y lo agarró un soldado diciéndole mire Vuestra Merced lo que hace, que es el gobernador de la provincia; mire Vuestra Merced que se pierde; respondio, no me perderé que mi corona queda libre» ${ }^{84}$.

Cuando el gobernador intentó arrestar a Gallardo, la mestiza Maria Josepha Alvarez, quien vivía en la casa del cura, gritó «purilapan, purilapan» (Quechua: corran todos) y concurrieron «indios por todas partes hasta que vieron libre a su cura». El tumulto fue tan grande que el gobernador y los soldados tuvieron que retirarse del pueblo «para aplacar la sedision». El informe indica que Gallardo mandó a llamar a Arteaga, quien después de escucharlo, le dijo que iba a golpear al gobernador:

... siento no aver llegado a tiempo, que yo lo hubiera dado ciento; ahora boi a darserlos y partiendo para la calle lo contubieron, diciendole que ya se avia ido... volvio a entrar para dentro y dijo al otro cura, compañero es preciso, que ahora traigan esse perro que el governador nombro para alcalde para despedazarlo con doscientos azotes por aver admitido la vara ${ }^{85}$.

Como pruebas producidas desde la perspectiva e interés de la Corona, la veracidad de tales testimonios, que a veces se presentan como citas directas, es cuestionable. Sin embargo, hay que reconocer el énfasis del documento preparado por Santa de Ortega en demostrar que los curas de Tarma se con-

de 1757, AAL, Capítulos: Carhuamayo, Ninacaca, legajo 31, exp.10. Don Phelipe Manrique Obispo de Guamanga autorizando la apelación de Don Joseph Gallardo Cura, y Vicario de la Doctrina de Ninacaca, 31 de Agosto 1758, AAL, Apelaciones: Huamanga, legajo 27, exp.6.

${ }^{84}$ Alfonso Santa de Ortega, corregidor de Canta, informa sobre la investigación que ha realizado relativo al tumulto y desordenes producidos en Ninacaca y Carhuamayo contra Pablo Sanz de Bustamante, 21 de Marzo de 1757, AGN, SG, legajo 12, exp. 210.

85 Idem. 
sideraban libres de la justicia secular, implicando que sus acciones delictivas se debían a esta inmunidad.

Santa de Ortega basó la acusación en contra de los curas Arteaga y Gallardo en dos leyes que se encuentran en la Recopilación de Indias. La primera es la Ley 73, Título 14, Libro 1, ya mencionada, que norma que las autoridades y justicias reales no hagan informaciones públicas ni secretas contra ningún religioso «salvo quando el caso fuere publico y escandaloso». En tal caso, se podía hacer informaciones secretas para requerir al prelado un castigo conforme al exceso. De no ser el castigo apropiado, se debía enviar la información al Consejo de Indias «para que provea lo que convenga y sea justicia» ${ }^{86}$. La segunda es la Ley 38, Título VI, Libro I, que afirma que los beneficios y oficios eclesiásticos no son permanentes sino removibles y que por común consentimiento del prelado y quien representa el Real Patronazgo pueden remover a cualquier doctrinero sin derecho a apelación ${ }^{87}$.

Santa de Ortega señaló que los curas Arteaga y Gallardo habían injuriado antes a la jurisdicción secular, liberando a dos presos arrestados por autoridades reales. Los dos curas también explotaban sin piedad a los indios en sus doctrinas, forzándolos a comprar mercancías a precios elevados y obligándolos a trabajar en parcelas agrícolas que los curas se habían apropiado. También, en las casas de ambos curas vivían mujeres de mala reputación. En Carhuamayo, el cura Arteaga había aumentado el diezmo y comerciaba con los productos y servicios de flete de los indios. Él también estaba detrás de declaraciones y memoriales falsos presentados por indios a la audiencia que acusaban al gobernador de agravios y desprestigiaban su elección del alcalde indio. Arteaga había fingido firmas y mandado a declarar a indios que no eran originarios de la doctrina ${ }^{88}$.

La provisión de ruego y encargo pedía al arzobispo ordenar a los curas Gallardo y Arteaga comparecer en Lima en el plazo de quince días, pero ninguno de los dos se presentó. Sólo después de una segunda provisión, Gallardo compareció en Lima, pero Arteaga, aduciendo falta de salud, se quedó administrando los dos curatos ${ }^{89}$. Santa de Ortega no pretendía juzgar a los curas en la justicia ordinaria pero insistió que el arzobispo debía ordenar

86 Recopilación de Leyes de los Reynos de las Indias..., 1791, Ley 73, Título 14, Libro 1: 123.

87 Ibidem, Ley 38, Título VI, Libro I: 47.

88 AGN, SG, legajo 12, exp. 210. José Romero, por si a su nombre de la doctrina de Ninacaca en Tarma, contra Pablo Saenz de Bustamante, gobernador de esa provincia por agravios, 29 de Enero de 1757, AGN, SG-Otros Fondos-Contencioso, legajo 40, exp. 1607.

89 AGN, legajo 12, exp. 210. 
prisión y embargo de bienes para ambos curas hasta la apropiada imposición de penas. Señalando que Arteaga era el principal autor del alboroto «por mas osado y resuelto», Santa de Ortega afirmó que este cura debía ser trasladado inmediatamente a Lima para quitar «el origen de las sediciones de la Provincia pues permaneciendo en ella, podian haver cresido los daños en la cituacion de hallarse los Indios juntos a el revelbe» ${ }^{90}$.

En lugar de comparecer, Arteaga escribió a la audiencia a nombre de ambos curas, tratando de demostrar que lo actuado por la justicia secular era una profanación de la jurisdicción eclesiástica. Arteaga denunció que las sumarias se habían conducido en el pueblo de Pasco, obligando a los declarantes a favorecer al gobernador afirmando que el cura no volvería a su parroquia. Arteaga acusó a Sanz de Bustamante de tener vicios embarazosos y pidió que se retire de la provincia para la recomendable libertad de los testigos, «dando por nulo lo assi actuado, como coactivo, y apacionado: debido Vuestra Merced suspender, y corregir el haverme mesclado en lo que puramente pertenece a la Jurisdiccion Eclesiastica» ${ }^{91}$.

Arteaga presentó un argumento bastante erudito para declarar «la incapacidad secular en las cauzas ecleciasticas». Él explicó que los emperadores romanos Honorio, Teodosio y Arcadio habían determinado que sólo la autoridad episcopal podía decidir sobre causas eclesiásticas, y citó numerosos teólogos, tales como Martin Bonacina (1585-1631), Fernando Castro Palao (1581-1633) y Francisco Suarez (1548-1617), que argumentaban que los clérigos eran del todo inmunes a la jurisdicción real. Arteaga también mencionó dos reales cédulas, de 1662 y 1666, en las que correspondientemente se reprendía al presidente y oyentes de la audiencia de Quito por haber hecho informaciones sumarias contra el provincial de aquel obispado, y se confirmaba la disposición real de que sólo la Iglesia podía aplicar remedios referentes a abusos de indios por curas ${ }^{92}$.

Arteaga también escribió que no se cuestionaba la excepción de los militares a la justicia ordinaria, aún cuando esta no había sido fundada en derecho alguno, sino en etiqueta política. Por lo tanto, «que Razon se podra alegar a la subexcion, que se experimenta en la fractura de la libertad ecleciastica; quando su esempcion tiene su Raiz en el derecho divino». En re-

90 En cumplimiento del superior orden de V.E. para que pasare a esta Provincia averiguar el tumulto con que las Yndias, e Yndios de ella faltaron al debido respeto, y obediencia a su Gobernador Don Pablo Saenz de Bustamante, 11 de Enero de 1957, AAL, Capítulos: Carhuamayo, Ninacaca, legajo 31, exp.10.

91 AGN, legajo 12, exp. 210.

92 Idem. 
lación a que justicias reales pudieran realizar informaciones sumarias de curas involucrados en casos públicos y escandalosos, Arteaga sugiere que «el haverle dado un Palo el otro Cura de Ninacaca al expressado Governador de Provincia» no califica como tal porque «no se ofrecio en el referido lance la menor sublebacion, que pueda apoyar la perturbacion de la paz pues (como se ha supuesto) parece no conforme a la jurisdiccion secular la entrada a este juicio». Por último, Arteaga repite que de acuerdo a la Bula de la Cena, In Coena Domini, todo el que procesa a eclesiásticos «esta excomulgado» ${ }^{93}$.

En sus argumentos, ambas partes enfatizaban la poca confiabilidad que merecían los indios en afirmar la verdad. El corregidor Santa de Ortega alegó que los curas delincuentes usaban de la astucia de prevaricar a los testigos. Según él, la «facilidad de los Yndios en hacer, y decir lo que quieren sus superiores, da mucho motivo a esta trampa, o cautela; y apenas se podra dar otra contraria que la desvarate» ${ }^{94}$. Arteaga, por su lado, criticó como el gobernador hacía que los testigos indios declaren a su favor. La «pusilanimidad de los Yndios» ${ }^{95}$, su supuesto poco ánimo y falta de valor, implicaba una falta inherente de principios morales para defender la ver$\operatorname{dad}^{96}$

Cuando el fiscal Diego Holgado intentó presentar sumarias detalladas de los excesos, los magistrados eclesiásticos, invocando los problemas causados por la ordenanza del duque de la Palata y las protestas del Melchor de Liñan, se negaron a utilizarlas ${ }^{97}$. La Corona sólo podía influir en tales acciones legales indirectamente, ya sea a través de la persuasión oral o por medio de las informaciones sumarias como evidencia de la injusticia, pero los jueces eclesiásticos, ejerciendo su autonomía jurídica, podían disponer de ellas.

93 Idem.

94 Sumaria Información producida por el General Dn. Alfonso Santa de Ortega, Corregidor y Justicia Mayor de la Provincia de Canta, juez nombrado para la investigación del tumulto y desordenes producidos en el Pueblo de Ninacaca y Carguamayo y los agravios inferidos a Dn. Pablo Sanz Bustamante, Gobernador de Ninacaca, 1 de Abril de 1757, AGN, SG, legajo 35, cuaderno 707.

95 Idem.

96 Para criollos y españoles, el supuesto carácter pusilánime de los indios determinaba que fueran pasivos ante el abuso, que les quiten las tierras o que pierdan batallas. Véase O'Phelan, 2001: 14. Juan y De Ulloa, 1826: 673. Urrutia y las Casas, 1847 [1808]: 78.

97 COR, Folio Rich 83, 27r-33v. 


\section{LOS JUICIOS ECLESIÁSTICOS}

Es importante considerar que las sentencias de los tribunales eclesiásticos han estado sujetas a revisiones por parte de la Corona a lo largo del período colonial. Sin embargo, estas tenían el propósito de proporcionar a los clérigos acusados la oportunidad de recibir un indulto o la revocación de sus sentencias. Estas apelaciones al rey requerían una petición formal al Consejo de Indias o a una audiencia ${ }^{98}$. Para revocar una decisión de un tribunal eclesiástico que la Corona consideraba insatisfactoria, no existía ningún procedimiento, ya que esto era considerado una violación de la inmunidad clerical. Una apelación real, por lo tanto, no podía simplemente revocar la decisión de los tribunales eclesiásticos.

De acuerdo al virrey Amat y Junient, los juicios eclesiásticos eran largos, engorrosos y manipulados. Mientras se investigaban los hechos, los curas solían presentar una serie de demandas, réplicas y alegatos a su favor que mezclaban la verdad con la falsedad ${ }^{99}$.

\section{El juicio al cura de Chancay Joseph Xavier de Vargas}

En la real cédula del 28 de noviembre de 1771, expedida por Carlos III, se había pedido a Amat y Junient que explique por qué Vargas, el cura de Chancay, no había sido llevado a juicio. Sin embargo, Vargas sí fue enjuiciado por el tribunal eclesiástico. En el juicio, se hizo todo lo posible para desacreditar al teniente de corregidor.

El juez eclesiástico, el canónigo Don Francisco de Espinosa escribió la sentencia el 20 de junio de 1758, afirmando que De la Mata no había logrado demostrar que era justicia mayor, «como lo ha supuesto toda esta causa». Él sólo era un juez de comisión, para los casos cuando el justicia mayor estaba ausente. Antes del atropellamiento, De la Mata y Vargas ya habían tenido desacuerdos. El cura había protegido a una mujer que tenía una disputa con el teniente de corregidor por un proceso de herencia. De la Mata, además, había sido incapaz de probar que Vargas había encarcelado al alcalde indio por no pagar excesivos honorarios eclesiásticos. Su encarcelamiento, el juez manifestó, «no fue por Deuda, sino por el delito de insexto cometido por dicho Matheo Barva con sobrina carnal de su mujer difunta, y ha verse fingido dispensado, y casado con ella siendo de todo falso». El juez también re-

\footnotetext{
98 Farriss, 1968: 67.

99 Amat y Junient, 1947: 9-10.
} 
chazó los testimonios de los indios contra el cura, argumentando que se habían realizado bajo el poder de De la Mata, y concluyó que cuando Vargas y De la Mata se estaban peleando por la llave de la cárcel, la intención del cura era liberar al prisionero ${ }^{100}$.

De acuerdo al juez, Vargas fue provocado por la negativa de De la Mata de entregar las llaves, pero el cura no debió haberse excedido «en las injurias que profirió contra dicho Don Francisco». A pesar que De la Mata también enfrentó e insultó al cura, este debió haberse moderado «con el sufrimiento, mansedumbre, y paciencia que corresponde a su cargo, y caracter». Por ninguna razón, debió injuriar a De la Mata, ni faltar al ejemplo que le debe a sus feligreses ${ }^{101}$.

Irónicamente, Espinosa sentenció a ambos, al acusado y al demandante:

Devo condenar, y condeno al dicho Don Joseph Xavier de Vargas en que no buelva á dicha Villa de Chancay por termino de tres años... Y por lo que resulta contra dicho Don Francisco de la Mata, lo condeno en cien pesos aplicados en la forma ordinaria y que se le aperciva el respeto que deve tener á su cura, y Pastor ${ }^{102}$.

De la Mata consideró que no se había hecho justicia. En julio de 1758, él apeló al tribunal eclesiástico de Huamanga, pero el procedimiento no llegó muy lejos porque en agosto del mismo año, Vargas murió ${ }^{103}$.

\section{Los juicios a los curas de Tarma Manuel de Arteaga y Joseph Gallardo}

Al asignar el caso al cura Ventura Cabello, el arzobispo Barroeta le instruyó hacer comparecer a los acusados a Lima y le dio «toda la facultad necesaria en derecho, con la de discernir censuras, ligar y absolber huellas, e invocar en caso necesario el auxilio del brazo secular» ${ }^{104}$. El tribunal eclesiástico sí acató la insistencia de Santa de Ortega de ordenar prisión y embargo

100 Causa Criminal seguida por Don Francisco de la Mata, Justicia Mayor de la Villa de Chancay; contra el Doctor Don Joseph Javier de Vargas Cura y Vicario de la Villa de Chancay, por agresiones reales y verbales cometidas en la persona de De la Mata, 18 de Diciembre de 1756, AAL, Capítulos: Carhuamayo, Ninacaca, legajo 38, exp.28.

101 Idem.

102 Idem. Como referencia del valor del peso, en la Diócesis de Cusco en 1791, el sacerdote con ingresos más bajos recibió 737 pesos anuales, mientras que aquel con ingresos más altos obtuvo 9.759. Véase Cahill, 1984: 243.

103 Idem.

104 AAL, legajo 27, exp. 6. 
de bienes para Arteaga y Gallardo hasta la apropiada imposición de penas ${ }^{105}$. Sin embargo, al igual que en el juicio al cura de Chancay, el juez eclesiástico enfatizó testimonios que mancillaban al demandante.

Al comparecer en Lima, el cura Gallardo trajo testigos indios que argumentaron que los testimonios obtenidos por Santa de Ortega habían sido obtenidos bajo coacción, que el alcalde nombrado por el gobernador era un «forastero», y que el cura Gallardo se había defendido con su bastón, después de que el gobernador lo había agarrado por el cuello y ordenado a sus soldados que lo aten ${ }^{106}$. Testigos entrevistados posteriormente agregaron que era «practica asentada» que los indios nombren tres sujetos ante su cura para elegir el alcalde. También manifestaron que Arteaga no realizaba el repartimiento de bienes en su doctrina; más bien, era el gobernador quien lo hacía y el cura le había solicitado que no imponga precios muy elevados. Otras acusaciones se referían al menosprecio del gobernador por la jurisdicción eclesiástica. Unos testigos afirmaron haber oído al gobernador decir que él tenía una cédula del rey ordenando que los curas no cobren obvenciones de ninguna clase. Otros testigos señalaron que Sanz de Bustamante había afirmado que en él residía la autoridad del Real Patronato y que él atropellaba e enfuriaba a los eclesiásticos, amenazándolos con que «los prendera y quatro caballos los pondra en San Pedro» ${ }^{107}$. Como argumenta Nancy Farriss, la evidencia presentada en los tribunales eclesiásticos estaba a menudo en contradicción directa con las pruebas reunidas por las autoridades seculares ${ }^{108}$.

El 26 de abril de 1758, el mismo juez eclesiástico, Francisco de Espinosa, absolvió al cura Manuel de Arteaga, «teniendo presente que la culpa que se le ha provado, no es digna de mas pena que la que ha padecido en la prisión de su persona y embargo de bienes». Días después, el 2 de mayo de 1758, Espinosa sentenció al cura José Gallardo a pagar 100 pesos, tomando en consideración su pobreza y que también ya había sufrido prisión y embargo de bienes. El juez culpó a Josepha Alvarez de haber causado el tumulto y advirtió a Gallardo que respete a los jueces reales, observe moderación en sus acciones y palabras, propias de su estado como sacerdote, y se abstenga de todo comercio. También advirtió a ambos curas que si se repetían quejas en

105 El Provisor y Vicario General del Arzobispado de Lima remite los autos que se siguen contra Manuel de Arteaga, cura de Carhuamay,o y José Gallardo, cura de Ninacaca, Tarma por tumultos, apropiación de jurisdicción real y agravios, 26 de Mayo de 1758, AGN, SG, legajo 12, exp. 217.

106 AAL, legajo 27, exp. 6.

107 AGN, legajo 12, exp. 217.

108 Farriss, 1968: 110. 
su contra se les impondrían las más graves penas hasta privarles de sus beneficios, como impone el derecho. Con respecto a sus puestos, Espinosa indicó que ambos curas no se restituyan a sus doctrinas hasta nueva orden ${ }^{109}$.

El virrey Manso de Velasco manifestó su disconformidad con las sentencias, y el 17 de julio de 1758, el fiscal del crimen apeló, esta vez al tribunal eclesiástico de Huamanga, insistiendo en «que el Juez apostolico remedie los excesos que se contienen en la sumaria secular y proceso eclesiástico» ${ }^{110}$. Los documentos del caso terminan con la aceptación de la apelación en Huamanga. No sabemos si el juicio allí se llegó a realizar, pero la disconformidad posterior de la Corona indica que no cambiaron las cosas. Trece años después, en la real cédula de noviembre de 1771, se enfatiza que esta falta de una sentencia apropiada demostraba lo inadecuados que eran los tribunales eclesiásticos, «de forma que siempre que no usado el medio de la concordia, se elija el de seguir autos judiciales, no se impondrá á los delinquentes el condigno castigo, ni se remediarán tales excesos» ${ }^{111}$.

Para entonces, cuando se instruyó al virrey Amat y Junient a que convoque al cura Arteaga para reprenderle, él era un racionero en la Catedral de Lima ${ }^{112}$. En la misma cédula, se hace hincapié en la soberanía del rey por derecho divino, como lo declara el Regalismo, y se especifica cuál debe ser el castigo adecuado para incidentes similares:

... usando de mi suprema potestad, que no reconoce mas superioridad que la de el mismo Dios, de quien la he recivido, extrañando de mis Dominios, y ocupando las temporalidades de los Eclesiásticos de cualquiera clase ó Dignidad que perturben la paz pública, ó insulten, y ofendan á los que en mi Real nombre goviernan y administran justicia... á cuyo medio será preciso ocurrir... si en los casos que ocurran de estas mismas circunstancias, no se mudare de conducta en los tribunales eclesiásticos, y se pronunciaren las sentencias con la imposicion de las penas correspondientes á la gravedad de los excesos, que cometen los Eclesiásticos, de modo que ellos queden corregidos, satisfecha la justicia, y reparado el escánda$10^{113}$.

El virrey, en su Relación de Gobierno, corroboró esta decisión,

... en virtud de lo que por la referida Rl. Cedula de 28 de noviembre de 1771 , se advierte el desagrado grande que han causado á S.M. los procedimientos de

\footnotetext{
109 AGN, legajo 12, exp. 217.

110 Idem.

111 COR, Folio Rich 83, 1r-3r.

112 Idem. Gaceta de Lima..., 1982 [1765]: 260.

113 COR, Folio Rich 83, 1r-3r.
} 
dichos Eclesiasticos, y que en casos semejantes que no se les imponga la condigna pena por los Crimenes que cometieren, se proceda al estrañamiento de los dominios de su S. M. ${ }^{114}$

Las órdenes reales para desterrar a sacerdotes indisciplinados no eran algo nuevo. Dos siglos antes, en una cédula del 30 de julio de 1588, expedida por el rey Felipe II, se había comunicado algo similar al arzobispo de Lima ${ }^{115}$. En 1771 , sin embargo, las instrucciones se dirigieron no al arzobispo sino al virrey, poniendo en práctica las políticas hacia el predominio de la jurisdicción secular sobre la eclesiástica.

Los casos deben ser interpretados en una perspectiva más amplia en la que la intervención directa estaba madurando. En 1783, la Junta del Nuevo Código de Indias preparó nuevas leyes que autorizaban a magistrados reales a juzgar a curas que cometieran delitos graves; y en 1795, Carlos IV derogó la inmunidad personal del clero para tales delitos ${ }^{116}$. Estas leyes indicaban que no debía «extenderse la inmunidad a los perpetradores de tan perjudiciales delitos que quedarían impunes si se dexase su castigo a sola la Potestad Eclesiastica por ser insuficiente para ello» ${ }^{117}$. Además, señalaban que a los delitos «graves o atroces» había que añadir los mayores de motines, levantamientos y sediciones, y que «cuando la sedición sea en contra de la seguridad de una plaza comandante militar de ella, oficiales y tropa que la guarnecen ha de tener el conocimiento la justicia militar y no la Real» ${ }^{118}$.

\section{CONCLUSIONES}

A pesar de que hizo todo lo que estaba a su alcance, la Corona no logró que se castigara satisfactoriamente a los curas acusados. El tribunal eclesiástico, prescindiendo de las sumarias preparadas por la justicia real y desprestigiando a los demandantes, protegió a los curas y reafirmó la autonomía de la inmunidad eclesiástica. Sin embargo, más de una década después, la Corona recordó y aprovechó ambos casos para imponer una nueva situación de creciente intervención en la disciplina eclesiástica. En la real cédula de no-

114 Amat y Junient, 1947: 10-11.

115 Al Arzobispo de los Reyes acerca de las penas para el clero sedicioso, 30 de Mayo de 1788, COR, Folio Rich 83, 86r-86v.

116 Farriss, 1968: 173. Lynch, 2012: 70.

117 Recopilación de Leyes de los Reynos de las Indias..., 1791, Ley 12, título IX. De la Hera, 1960: 555.

118 Ibidem, Ley 13, título XII. De la Hera, 1960: 556. 
viembre de 1771, la Corona, más que reprender al único cura sobreviviente, aseveró la nueva legitimación del poder real por derecho divino. Sin otro superior que Dios mismo, el rey asumió la potestad suprema de desterrar a los curas que no fueran apropiadamente castigados por el tribunal eclesiástico.

La Corona acompañó esta advertencia al clero con una crítica a la justicia eclesiástica, usando los casos para demostrar a la Iglesia que la inmunidad personal del clero llevaba a los curas a cometer atropellos y que los tribunales eclesiásticos eran incapaces de imponer penas adecuadas. Para entonces, por la acumulación de problemas que había causado a la administración virreinal, la Corona ya había removido a Barroeta del arzobispado de Lima. Esta acción, una prerrogativa real de última instancia, limitó las posibilidades de los eclesiásticos de oponerse abiertamente a las reformas cuando fueron implementadas legalmente. Esto contribuye a explicar por qué en el virreinato del Perú hubo poca obstrucción clerical a la imposición de límites a la inmunidad del clero en asuntos de disciplina.

Cuando el cura Arteaga explicó las razones por las cuales la justicia secular no debía ni estaba capacitada para juzgar eclesiásticos, él recurrió a dos conceptos: la tradición como derecho y el origen divino de la inmunidad del clero. En el orden jurídico de la sociedad colonial, como afirma Sergio Serulnikov, la tensión y el litigio eran constantes porque los privilegios corporativos se legitimaban en el reconocimiento de la tradición como derecho y no en el derecho como ley ${ }^{119}$. El proyecto regalista pretendía sobrepasar a la tradición como derecho y resolver el estado de conflictividad constante a que conducía. La influencia regalista, ausente en el argumento de Arteaga, es evidente en la carta del obispo y el cabildo de Puebla, Nueva España, al rey Carlos IV en 1799, en defensa de la inmunidad personal del clero. En vez de enfatizar un origen divino de los privilegios de los eclesiásticos y su legitimación en la tradición como derecho, en la carta se afirma que estos «no dimanan de otro principio que de la Suprema Real Potestad» y se recurre a afirmaciones pragmáticas para defenderlos, argumentando que su pérdida causará que los curas queden expuestos a la indignidad y el desprecio ${ }^{120}$.

Por último, el cura Arteaga no había golpeado al gobernador; sin embargo, la Corona se empeñó en castigarlo judicialmente. Detrás de esta insistencia estaba el temor de que las transgresiones de los curas, ya sea explotando o movilizando a los indios, pudieran desembocar en rebeliones generalizadas. Tanto el fiscal, el virrey, y los secretarios del rey enfatizaron que el caso de Tarma era más grave por la posibilidad de que los indios del área se sumaran

119 Serulnikov, 2012.

120 Obispo y Cabildo de Puebla, 1960 [1799]: 568-9. 
a Santos Atahualpa o empezaran otra rebelión. En la «era de insurrección andina» ${ }^{121}$, autoridades reales culparán a los clérigos tanto por la rebelión de Santos de Atahualpa como por la de Tupac Amaru II ${ }^{122}$.

\section{Fuentes PRIMARIAS IMPRESAS y REFERENCIAS BIBLIOGRÁfiCAS}

Amat y Junient, Manuel de, Memoria de Gobierno de Manuel de Amat y Junient, virrey del Perú, 1761-1776, Sevilla, Escuela de Estudios Hispanoamericanos, 1947.

Amich, José, Compendio histórico de los trabajos, fatigas, sudores y muertes que los ministros evangélicos de la seráfica religión han padecido por la conversión de almas de los gentiles, en las montañas de los Andes, pertenecientes a las provincias del Perú, Paris, Librería de Rosa y Bouret, 1854.

Andrien, Kenneth, "The Coming of Enlightened Reform in Bourbon Peru: Secularization of the Doctrinas de indios, 1746-1773", Gabriel Paquette (ed.), Enlightened Reform in Southern Europe and its Atlantic Colonies, C. 1750-1830, Farnham, Ashgate Publishing, 2009: 183-202.

Barroeta y Ángel, Pedro, "Carta del Ilmo Pedro A. o de Barroeta y Angel para Ilmo. Sr. Dn. Manuel Quintano Bonifaz, Arzobispo de Farsalia e Inquisidor General", Carmen Martínez Martín, "El Ilmo Pedro A. ${ }^{\circ}$ de Barroeta y Ángel: Un conflictivo arzobispo en la Iglesia de Lima (1751-1758)", Berceo, 154 (Logroño, 2008): 168172.

Brading, David, "El clero mexicano y el movimiento insurgente de 1810", Relaciones, 2/5 (Zamora, 1981): 5-26.

Cahill, David, "Curas and Social Conflict in the Doctrinas of Cuzco, 1780-1814", Journal of Latin American Studies, 16/2 (Cambridge, 1984): 241-276.

Crahan, Margaret, "The Administration of Don Melchor de Navarra y Rocafull, Duque de la Palata: Viceroy of Peru, 1681-1689”, The Americas, 27/4 (Cambridge, 1971): 389-412.

Crahan, Margaret, "Church-State Conflict in Colonial Peru: Bourbon Regalism Under the last of the Hapsburgs", The Catholic Historical Review, 62/2 (Baltimore, 1976): 224-244.

De la Hera, Alberto, "Reforma de la inmunidad personal del clero en Indias bajo Carlos IV", Anuario de Historia del Derecho Español, 30 (Madrid, 1960): 553-616.

121 Stern, 1990: 50.

122 Jones, 2009: 28. Walker, 2008: 62, 82 y 255. 
De la Hera, Alberto, "El regalismo indiano", Pedro Borges (ed.), Historia de la Iglesia en Hispanoamérica y Filipinas (siglos XV-XIX), Madrid, Biblioteca de Autores Cristianos, 1992: 81-97.

Escamilla, Francisco, "Inmunidad eclesiástica y regalismo en Nueva España a fines del siglo XVIII: El proceso de fray Jacinto Miranda", Estudios de Historia Novohispana, 19/19 (Ciudad de México, 1998): 47-68.

Farriss, Nancy, Crown and Clergy in Colonial Mexico 1759-1821: The Crisis of Ecclesiastical Privilege, London, The Athlone Press, 1968.

Fisher, John, El Perú borbónico 1750-1824, Lima, Instituto de Estudios Peruanos, 2000.

Gaceta de Lima. De 1762 a 1765, Lima, COFIDE, 1982 [1765].

Jaramillo, Juvenal, Hacia una iglesia beligerante, Zamora, El Colegio de Michoacán, 1996.

Jones, Cameron, The will of God and the will of the King: The missionaries of Ocopa and conflicts between Church and State in mid-eighteen century colonial Peru (M. A.), Columbus, The Ohio State University, 2009.

Juan, Jorge y Ulloa, Antonio de, Noticias secretas de América, Londres, R. Taylor, 1826.

Kuethe, Allan J. y Andrien, Kenneth J., The Spanish Atlantic World in the Eighteenth Century: War and the Bourbon Reforms, 1713-1796, New York, Cambridge University Press, 2014.

Lynch, John, New Worlds: A Religious History of Latin America, New Haven, Yale University Press, 2012.

Manso de Velasco, José Antonio, Memorias de los virreyes que han gobernado el Perú durante el tiempo del coloniaje español, Lima, Librería Central de Felipe Bailly, 1859 [1756].

Martínez, Carmen, "El Ilmo. Pedro A. ${ }^{\circ}$ Barroeta y Ángel: Un conflictivo arzobispo en la iglesia de Lima (1751-1758)", Berceo, 154 (La Rioja, 2008): 139-172.

Millar Carvacho, René, "Los conflictos de competencia de la inquisición de Lima", Revista Chilena de Historia del Derecho, 12 (Santiago, 1986): 95-128.

Moreno Cebrián, Alfredo, "Introducción", Relación y documentos de gobierno del Virrey del Perú, José A. Manso de Velasco, Conde de Superunda (1745-1761), Madrid, Instituto 'Gonzalo Fernández de Oviedo', 1983: 17-30.

Obispo y Cabildo de Puebla, "Carta del Obispo y el Cabildo de Puebla de los Angeles al Rey Carlos IV, sobre las disposiciones del Nuevo Código de Leyes de Indias referentes a la inmunidad eclesiástica (18 de noviembre de 1799)", Alberto De la Hera, "Documentos: Reforma de la inmunidad personal del clero en Indias bajo 
Carlos IV", Anuario de historia del derecho español, 30 (Madrid, 1960 [1799]): 553-616.

O’Phelan, Scarlett, La gran rebelión en los Andes: De Túpac Amaru a Túpac Catari, Lima, Petroperu, 1995.

O’Phelan, Scarlett, “Una rebelión abortada, Lima 1750: La conspiración de los indios olleros de Huarochirí", Varia Historia, 24 (Belo Horizonte, 2001): 7-32.

Paquette, Gabriel, Enlightenment, Governance, and Reform in Spain and its Empire 1759-1808, Londres, Palgrave Macmillan, 2011.

Pérez-Mallaína, Pablo, Retrato de una ciudad en crisis: La sociedad limeña ante el movimiento sísmico de 1746, Sevilla, CSIC, 2001.

Recopilación de leyes de los reynos de las Indias mandadas a imprimir y publicar por la magestad católica del Rey Don Carlos II, Madrid, Real y Supremo Consejo de las Indias, 1791.

Ricketts, Mónica, "The Rise of Bourbon Military in Peru, 1768-1820”, Colonial Latin American Review, 21/3 (Londres, 2012): 413-439.

Rosas Lauro, Claudia, El miedo en el Perú: Siglos XVI al XX, Lima, PUCP, 2005.

Ruiz Peralta, Víctor, "Las razones de la fe. La Iglesia y la Ilustración en el Perú, 1750-1800”, Scarlett O’Phelan Godoy (ed.), El Perú en el siglo XVIII. La era borbónica, Lima, PUCP, 1999: 205-242.

Santamaría, Daniel, "La rebelión de Juan Santos Atahuallpa en la selva central peruana (1742-1756). ¿Movimiento religioso o insurrección política?”, Boletín Americanista, 57/57 (Barcelona, 2007): 233-256.

Serulnikov, Sergio, "Representaciones, prácticas, acontecimientos. Apuntes sobre la historia política andina”, Memoria Americana, 20 (Buenos Aires, 2012): 89-110.

Spalding, Karen, Huarochiri: An Andean Society Under Inca and Spanish Rule, Stanford, Stanford University Press, 1984.

Stern, Steve, "La era de la insurrección andina, 1742-1782: Una interpretación", Steve J. Stern (ed.), Resistencia, Rebelión y Conciencia Campesina en los Andes siglos XVIII al XX, Lima, IEP, 1990: 50-96.

Taylor, William, Magistrates of the sacred: Priests and parishioners in eighteenthcentury Mexico, Stanford, Stanford University Press, 1996.

Torre López, Arturo, Juan Santos Atahualpa, Lima, PUCP, 2004.

Urrutia y las Casas, Ramón, Informe del Intendente Urrutia sobre las ventajas que resultan de la apertura del camino y comunicacion por el Chanchamayo, presentado al Virrey del Perú en 1808, Lima, Imprenta del Comercio, 1847 [1808].

Varese, Stefano, La Sal de los Cerros, Lima, Fondo Editorial del Congreso del Perú, 2006. 
Vargas Ugarte, Rubén, Historia de la Iglesia en el Perú, Burgos, Imprenta de Aldecoa, 1961.

Walker, Charles, "Desde el terremoto a las bolas de fuego: Premoniciones conventuales sobre la destrucción de Lima en el siglo XVIII", Relaciones, 25/97 (Zamora, 2004): 30-55.

Walker, Charles, Shaky Colonialism: The 1746 Earthquake-Tsunami in Lima, Peru, and its Long Aftermath, Durham, Duke University Press, 2008.

Fecha de recepción: 2 de diciembre de 2015.

Fecha de aceptación: 19 de julio de 2016.

\section{Disciplining Priests: The Personal Immunity of the Clergy and Royal Control in the Viceroyalty of Peru, 1755-1775}

In the last decades of the eighteenth century, the Bourbon Crown was determined to undermine the personal immunity of the clergy. Examining two assaults on royal authorities by priests serving in indigenous parishes, this research analyses the capacity for political manoeuvre of Crown and Church in the Viceroyalty of Peru, prior to the enactment of legal limitations to such exemption. One of the victims was the political and military governor of Tarma, who was in charge of suppressing the Indian rebellion of Juan Santos Atahualpa. Despite not getting the ecclesiastical tribunal to punish the priests to its satisfaction, the Crown took advantage of the dispute to strengthen a royalist position.

KeY words: Personal immunity of the clergy; ecclesiastical jurisdiction; Bourbon reforms; Viceroyalty of Peru. 